\title{
Article
}

\section{Understanding Apple Attribute Preferences of US Consumers}

\author{
Rombach Meike ${ }^{1, *} \mathbb{C}$, David L. Dean ${ }^{2}\left(\mathbb{D}\right.$ and Tim Baird ${ }^{2}$ \\ 1 Department of Land Management and Systems, Lincoln University, Lincoln 7647, New Zealand \\ 2 Department of Agribusiness and Markets, Lincoln University, Lincoln 7647, New Zealand; \\ david.dean@lincoln.ac.nz (D.L.D.); tim.baird@lincoln.ac.nz (T.B.) \\ * Correspondence: meike.rombach@lincoln.ac.nz
}

\section{check for}

updates

Citation: Meike, R.; Dean, D.L.; Baird, T. Understanding Apple Attribute Preferences of US Consumers. Foods 2022, 11, 166. https://doi.org/ $10.3390 /$ foods 11020166

Received: 1 December 2021

Accepted: 7 January 2022

Published: 9 January 2022

Publisher's Note: MDPI stays neutral with regard to jurisdictional claims in published maps and institutional affiliations.

Copyright: (c) 2022 by the authors. Licensee MDPI, Basel, Switzerland. This article is an open access article distributed under the terms and conditions of the Creative Commons Attribution (CC BY) license (https:// creativecommons.org/licenses/by/ $4.0 /)$.

\begin{abstract}
Apple preferences of US consumers are widely explored. However, the key factors that drive the importance that US consumers place on apple attributes are rather unexplored. To fill this literature gap, an online survey with 383 US apple buyers was conducted. A two-step analysis consisting of descriptive statistics and partial least squares structural equation modelling indicates that subjective knowledge was the most important factor, determining both the discernment of buyers and attitudes towards US fruit growers. Objective knowledge and sociodemographic factors, other than education, were not found to have any impact. The discernment of a buyer and their ability to distinguish apple varieties had the greatest impact on the importance that US consumers placed on physical and commercial product attributes. It was also found that attitudes towards growers impacted on the importance which consumers place on both types of attributes. Given that consumer attitudes were shown to be a strong driver of their buying preferences, growers and grower associations should also consider highlighting the positive health and societal benefits that their products provide.
\end{abstract}

Keywords: apple varieties; attitudes; knowledge; US consumers

\section{Introduction}

Fresh apples are a commonly consumed and widely available product in food markets around the world [1,2]. They are valued for their health benefits, which include being rich in Vitamin C and phenolic compounds [3,4]. In today's food markets, consumers have the choice to either buy domestically produced apple varieties or those that are sourced from overseas [5]. For the US, New Zealand is one of these overseas sources. New Zealand's reputation as a global leader in apple breeding, production and export makes sourcing apples from there attractive for overseas markets [6-8]. Seasonality can mean that apples grown in the US are insufficiently available, and this lack of supply is filled with Southern-Hemisphere produce. The main share of US apples is produced in Washington, Michigan, New York, Oregon and Pennsylvania [9]. These states are known for their large-scale production, technological innovation and being the home to many traditional and robot-ready apple orchards [10,11]. Traditional varieties, such as Honeycrisp, Fuji, Granny Smith, Red Delicious, and Golden Delicious, as well as club varieties, such as Jazz, Pink Lady, Sweet Tango, and Ambrosia [12,13], are popular among US consumers. This development towards modern apple varieties, as well as an increase in the level of investment in orchards, is evidence that the US apple industry is consumer-oriented and striving to provide products that satisfy the needs and wants of fruit consumers $[1,14]$.

Apples as a horticultural consumer good are comprised of various product attributes, some of which may have varying levels of importance for consumers. Relevant consumer attributes possessed by fresh apples include the colour of the skin, shape, aroma, apple variety, texture and the length of their shelf life [15-18]. This latter attribute is particularly important, as even though apples have good storing qualities, they are ultimately perishable [19-21]. Colour and appearance are crucial in retail situations as they attract the 
consumer's attention. Colour often serves as a cue for fruit quality; consumers commonly attempt to estimate the texture of apples as this gives them an indication of the taste [22]. Extant literature in this area classifies consumers into two main categories: those who prefer firmness, juiciness, and bit of acidity in apples, and those that who like sweeter, but less firm apples [23]. In addition to these product attributes which are inherent to the apple (intrinsic attributes), consumers are also interested in commercial attributes, such as price, packaging, branding, country of origin, and sustainability [24-26]. These are linked to the production, distribution, and presentation of apples (extrinsic attributes) [27-31]. Although early studies on horticultural and agricultural products have emphasised the importance of intrinsic attributes for consumers, more recent studies show that for agricultural and horticultural products external attributes are equally important for consumers [2,32-35]. Consumer choices regarding apple attributes, as well as the willingness to pay for fresh or processed apple products has been intensively studied in the US [12,36,37]; Consumer choice relies on a trade off between bundles of intrinsic and extrinsic product attribute; these include aspects of consumers personal backgrounds, including their sensory preferences and attitudes [38]. However, key-factors which lead to the determination of apple preferences are not as widely studied. In the following sub sections these factors are explained in more detail as they underpin the conceptual framework for this study. US consumers' objective and subjective knowledge, as well as their sociodemographic backgrounds, their discernment as a buyer and their attitudes towards apple growers are likely to be key factors in determining the importance that US consumers place on physical and commercial apple attributes.

\subsection{Objective and Subjective Consumer Knowledge}

Horticultural products, such as apples are information-intensive products [38], as many varieties exist. The type of production, such as organic and conventional production, influence orchard management, and ultimately the final product $[39,40]$. In order to receive information about food quality, food safety, and whether a product is local or not, consumers use different intrinsic and extrinsic attributes [36,40-42]. However, identifying this desired information is often not a straightforward task for consumers [35].

Understanding consumers' needs and wants, their behaviors and knowledge is essential for marketers in the US food retail industry to successfully target different fruit consumer segments. In terms of consumer knowledge, different types of knowledge, such as subjective and objective knowledge need to be distinguished [43].

Subjective knowledge is known as self-reported knowledge, and relies on consumers self-assessments and their perceptions, which may be incorrect [44]. Objective knowledge is correct and accurate knowledge, which is assessed through testing, and is stored in longterm memory of the consumer [44]. Objective knowledge can be obtained intentionally or unintentionally. Intentional knowledge occurs when consumers make a conscious effort to learn specific product information, while unintentional knowledge occurs when consumers are exposed to stimuli [44].

Subjective and objective knowledge are equally important when assessing consumers' apple knowledge [45]. However, the literature on both types of knowledge is inconclusive. Some studies emphasise the correlation between subjective and objective knowledge, and suggest that both types of knowledge are interconnected; other studies have shown that they can be different, and stress that subjective and objective knowledge are only inconsistently correlated [46]. Nevertheless, there is agreement that consumer knowledge impacts their preferences, and ultimately their buying behaviour $[45,46]$.

\subsection{Socio-Demographics}

Various studies discuss the socio-demographic backgrounds of US consumers who purchase fresh apples; however, there is no consensus in the body of literature on these socio-demographic backgrounds, and even less for preferences for specific apple attributes. Some studies indicate that buying apples is associated with gender, age, high income, 
and education [47]. Being female is also an important factor, as it has been reported that the majority of grocery shoppers in the US are women [12]. Other studies diverge from socio-demographic information as key factors. Instead, they highlight dietary preferences, attitudes, and lifestyle choices $[48,49]$. Given that there are differences in apples being offered in food retail across regions in the US, apple variety preferences across states or regions are very heterogeneous [12,50,51].

Studies being specifically dedicated to intrinsic and extrinsic apple attributes highlight that consumer preferences are heterogenic, and that consumer backgrounds are equally diverse [12,52]. Preferences for physical attributes, such as appearance, texture and taste are difficult to associate with socio-demographic backgrounds, This is due to consumers who are at the point of sale or who are participating in sensory experiments not always being able to correctly distinguish amongst these attributes, which makes it difficult to for the consumer to express their preferences [52-54]. In addition, various studies focus only on single attributes, or a few selected attributes [52-54].

\subsection{Apple Buyer Discernment}

For the US food retail industry, as well as for the horticultural industry, it is important to know consumer preferences for new and existing varieties, as well as their ability to distinguish varieties [52]. This allows businesses to offer products that consumers need and want, and enables marketers to differentiate their products from existing ones. Very few studies have focused on the perception of apple varieties and the ability of consumers to distinguish them [52]. Studies which have shown that consumers are necessarily able to distinguish apple varieties have found that mostly neophobia or neophilia determines preference or aversion towards new apple varieties [12,52]. In the US, new varieties are often termed as club varieties [12]. Club varieties are subject to patent-protection. Growers who are part of the club have exclusive rights to produce and market the club variety as stipulated by a licensing contract. This includes both fruit quality and quantity [55]. Common examples of club varieties on the US market are 'Jazz ${ }^{\mathrm{TM}}$ ', 'SnowSweet ${ }^{\circledR \prime}$, 'Sweet Sixteen', 'SweeTango ${ }^{\circledR}$, ' 'Zestar! ${ }^{\mathrm{TM}}$ ', and 'Pink Lady ${ }^{\circledR}$ ' [12]. Examples of more traditional varieties are 'Red' and 'Golden Delicious', 'Granny Smith', 'Fuji', 'Honeycrisp', 'McIntosh', 'Cripps Pink' [13]. Given that the majority of consumers do not possess a good varietal knowledge, marketing promotions, such as tasting experiences which offer free samples coupled with promotional materials regarding varietals are crucial to improve the ability of consumers to distinguish amongst different varieties [55].

\subsection{Attitudes towards Growers}

Attitudes refer to a learned tendency to evaluate things, people, or events either favourably or unfavourably [46]. Attitudes towards horticultural and agricultural production and growers are quite diverse. Although some studies report consumer trust and positive attitudes towards products, growers, and production processes, others report concerns, distrust, perceived risks, and negative attitudes [46]. Issues discussed in this context and which influence attitudes towards growers are challenges regarding production, technological innovation, disease and pest management, payments, treatment of labour and labour conditions, environmental impacts, and resource usage [56].

\subsection{Objective and Hypotheses}

Using the extant literature in this topic area as a foundation, this study aims to explore the drivers of US consumers apple attribute preferences. The theoretical framework (see Figure 1) is based on the literature presented. It is suggested that the importance that US consumers place on apple attributes is likely to be influenced by their sociodemographic background, their objective and subjective knowledge, their discernment as a buyer, and their attitudes towards horticultural growers. Consumer specific information, such as socio-demographic background and knowledge, can influence both the consumers' ability to distinguish apple varieties and their respective attitudes towards horticultural 
products, such as apples, and the growers of these products. Given that an attitude refers to a tendency to that is expressed by evaluating an entity either positively or negatively, consumer attitudes can impact the importance they place on apple attributes. Depending on their knowledge and attitudes, consumers may evaluate intrinsic and extrinsic product attributes either favourably or unfavourably $[12,45,46,52,55,56]$.

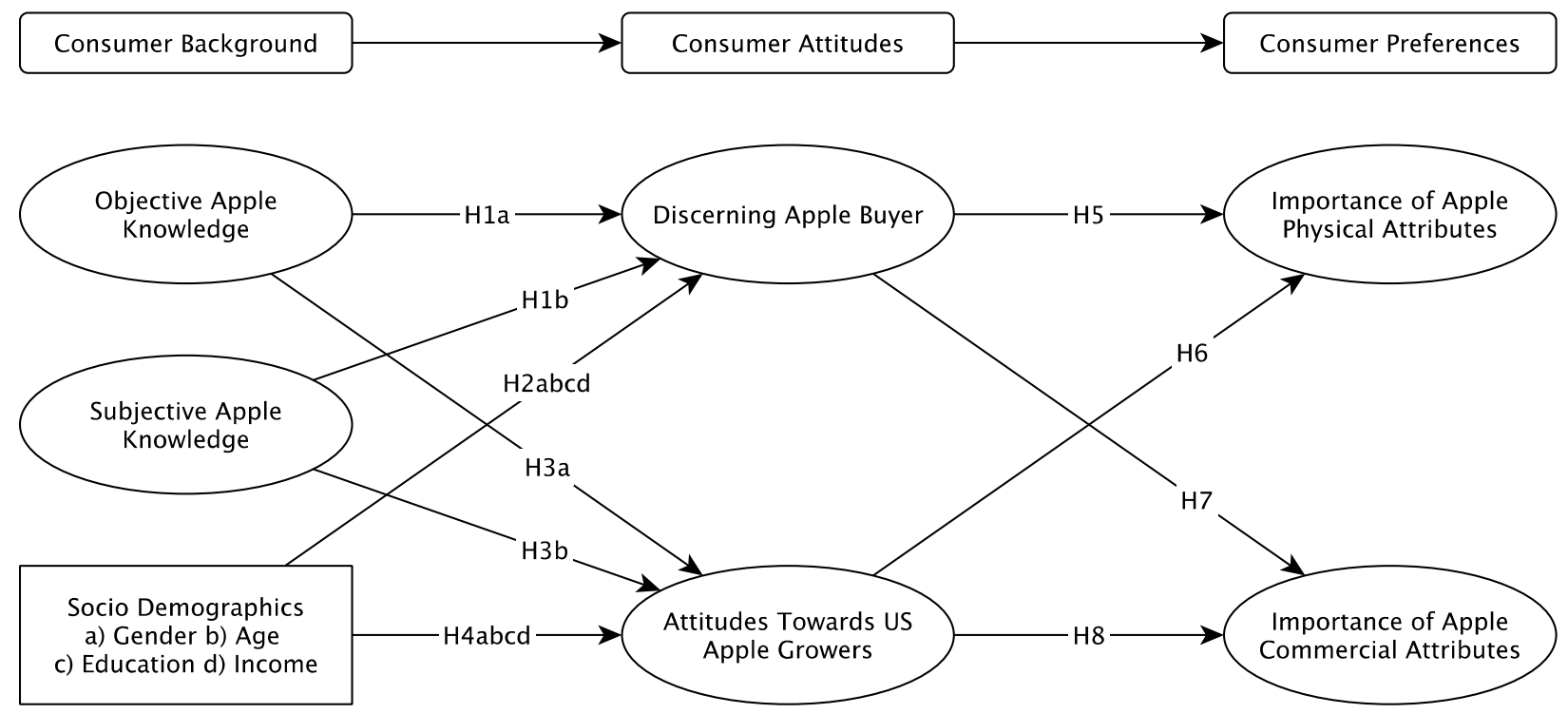

H1a: Objective Apple Knowledge -> Discerning Apple Buyer

H1b: Subjective Apple Knowledge -> Discerning Apple Buyer

H2: Socio Demographics -> Discerning Apple Buyer

H3a: Objective Apple Knowledge -> Attitudes towards US Apple Growers

H3b: Subjective Apple Knowledge $\rightarrow$ Attitudes towards US Apple Growers

H4: Socio Demographics -> Attitudes towards US Apple Growers

H5: Discerning Apple Buyer -> Importance of Apple Physical Attributes

H6: My Attitudes towards US Apple Growers -> Importance of Apple Physical Attributes

H7: Discerning Apple Buyer -> Importance of Apple Commercial Attributes

H8: My Attitudes towards US Apple Growers -> Importance of Apple Commercial Attributes

Figure 1. Conceptual Framework.

Hypothesis 1 (H1). Being a discerning apple buyer is likely to be positively impacted by (a) objective knowledge, and (b) subjective knowledge.

Hypothesis 2 (H2). Being a discerning apple buyer is likely to be positively impacted by (a) gender, (b) age, (c) education, and (d) income.

Hypothesis 3 (H3). Attitudes towards US apple growers are likely to be positively impacted by (a) objective knowledge, and (b) subjective knowledge.

Hypothesis 4 (H4). Attitudes towards US apple growers are likely to be positively impacted by (a) gender, (b) age, (c) education, and (d) income.

Hypothesis 5 (H5). The importance that consumers place on physical apple attributes is likely to be positively impacted by their discernment as an apple buyer.

Hypothesis 6 (H6). The importance that consumers place on physical apple attributes is likely to be positively impacted by their attitudes towards US growers.

Hypothesis 7 (H7). The importance that consumers place on commercial apple attributes is likely to be positively impacted by their discernment as an apple buyer. 
Hypothesis 8 (H8). The importance that consumers place on commercial apple attributes is likely to be positively impacted by their attitudes towards US growers.

\section{Material and Methods}

\subsection{Research Design and Data Collection}

In October 2021, an online survey was conducted to receive information about US consumers' apple preferences. The online survey software Qualtrics and Amazon Mechanical Turk, a crowdsourcing marketplace were used to distribute the survey $[57,58]$. The survey was designed to obtain information such as respondents' socio-demographic backgrounds, as well as respondents' knowledge about apples and apple production in the US. It was also designed to examine their perceptions and attitudes towards traditional and club varieties, as well as towards US growers. To participate in the survey, respondents needed to be 21 years old and reside in the US. The data collection resulted in 461 responses, of which 400 were apple consumers. Among these 400 consumers, 383 delivered complete responses that were suitable for analysis. The minimum sample consisted of 196 male and 187 female respondents targeted to be apple buyers. The required minimum sample size of 385 people was estimated via power analysis. The sample of 383 US apple buyers who completed the survey is appropriate for an analysis using descriptive statistics and partial least squares structural equation modelling (PLS-SEM), as the latter approach is particular suitable for small samples [59-61]. Applying the "10-times rule" is common convention in PLS-SEM. The rule states that the sample size needs to be greater than 10 times the maximum number of inner or outer model links pointing at any latent variable in the model [59-61].

Although many of the constructs have already been discussed in the literature, previous studies offer very few validated scales to adopt for the current research. Therefore, items were created from the relevant concepts proposed in the existing body of literature within this topic domain.

The importance of apple attributes (8 items) was measured using a 7-point importance scale $(1=$ Extremely unimportant to $7=$ Extremely important $)$, and were divided into physical attributes (4 items) and commercial attributes (4 items). The category of discerning apple buyer $(7$ items $)$ was measured using a similarity scale $(1=$ very dissimilar to $7=$ very similar) assessing perceived similarity between a number of apple varieties. Subjective apple knowledge (4 items) and attitudes towards US apple growers (6 items) was measured using 7 -point Likert scales $(1=$ strongly disagree to $7=$ strongly agree). The subjective apple knowledge scale included statements about apple understanding, confidence, and knowledge relative to others. The attitudes towards US apple growers included statements about their traditions, contributions, and social pressures. Finally, objective apple knowledge consisted of a series of multiple-choice questions about domestic and foreign apple production and labelling. The items consisted of 5 factual questions about these issues, and responses were scored with 1 for correct and -1 for incorrect resulting in an index with a possible range of -5 to +5 .

\subsection{Data Analysis}

SPSS was used in the management of the data and the calculation of descriptive statistics. PLS-SEM analyses, using SmartPLS, were employed to identify the significant determinant factors of the importance that US consumers place on physical and commercial apple attributes. PLS-SEM methods are widely applied in the social sciences [59], and they generally combine three analytical approaches; regression analysis, path analysis, and principal component analysis [60,61]. PLS-SEM methods are particularly appropriate in situations where researchers are dealing with small sample sizes, non-normally distributed data, and when explorative models contain causal dependencies amongst latent constructs [60]. A two-step approach was applied throughout the PLS-SEM analysis, starting with what is called model measurement (analysis of the inner model) followed by model structure (analysis of the inner model) [60,62]. 
Following the research of Hair et al. (2019), model measurement aims to verify that model is measuring the constructs correctly both within and between measurement scales. In order to enable this, reliability and validity testing was utilized [60] where loadings greater than 0.4 confirm that items contribute to their appropriate scale. Average variance extracted (AVE) scores greater than 0.5 indicate that the scales have met the variance of their proposed items. Checks for the reliability or internal consistency of scale items were carried out through utilizing both Cronbach's Alpha (>0.6) and composite reliability $(>0.6)$ measurements [63].

An evaluation of cross-loadings, as well as using the Fornell-Larcker criterion is a common approach to determine discriminant validity; this, in turn, confirms that scales are measuring distinct concepts and items belong to those scales $[60,63]$. Cross-loading checks ensure that a higher correlation is able to be obtained for all items with their appropriate factor, and this, subsequently, can make sure that other factors are not interfering with these results. The Fornell-Larcker criterion is satisfied when item correlations with the square root of the individual constructs' AVE is greater than correlations with other constructs [61,64]. Following the work of Henseler et al. (2015), discriminant validity is also measured using the Heterotrait-Monotrait ratio of correlations criterion (HTMT), and this is confirmed when a threshold value of 0.9 is achieved [65]. Finally, the variance inflation factor (VIF) can also be employed to search for high levels of multi-collinearity, and when this is under 5 , then the data are suitable for further analysis [60].

Step 2 in the PLS-SEM analysis, model structure, examines the predictive relevance of the model, the accuracy of its structural fit, alongside its explanatory power [61]. Although Hair et al. (2017) contend that SEM-PLS do not lend themselves to model fit indices [63], normal practice is to report both Normed Fit Index (NFI) and Goodness of Fit (GoF), where both NFI and GoF scores vary on a scale from 0 to 1 . Larger scores are indicative of a better fit. Smaller Standardised Root Mean Square Residual (SRMR) also indicates a better fit; however, values of more than 0.10 are noted as being problematic, while values which are of 0.08 or less are viewed as being acceptable.

The individual and average variance explained $\left(\mathrm{R}^{2}\right)$ of the dependent variables provides a foundation for the explanatory power of the model. Following Hair et al. (2017), values need to be interpreted as follows: while 0.75 classifies as sizeable, a variance of 0.5 is considered to be moderate, while a variance of 0.25 is considered to be weak [61]. The Stone Geisser criterion $\left(Q^{2}\right)$ estimates the predictive validity, which should be larger than zero [61]. Indications of medium and large predictive accuracy are shown by $\mathrm{Q}^{2}$-values that are larger than 0.25 and 0.5 [61].

\section{Results}

The descriptive statistics of the sample are displayed in Table 1 . The median respondent was aged between 25 and 34 years, had obtained a bachelor degree, and earned an annual pre-tax income ranging between USD 25,000 to USD 50,000 per year. Additionally, the other scale measured in the model was the objective apple knowledge score, which had a mean of 1.02 , a range of between -4 to +5 , and a standard deviation of 1.834 .

The measurement model assessment included the use of reliability to test the model constructs, as well as the use convergent and discriminant validity to conduct further checks. All items achieved a factor loading of well above the minimum of 0.4 , indicating their suitable contribution to the scale (see Table 2). Reliability was confirmed by both the Cronbach Alpha and composite reliability scores being above 0.6. Convergent validity was also indicated by AVE scores being higher than 0.5 for all the scales. Given that all indicators were within acceptable ranges, the requirements of construct reliability and validity were considered satisfactory [61]. 
Table 1. Sample description.

\begin{tabular}{|c|c|c|c|c|}
\hline & Freq & $\%$ & Median & StDev \\
\hline \multicolumn{5}{|l|}{ Age } \\
\hline Under 21 & 2 & 0.5 & & \\
\hline $21-24$ & 16 & 4.2 & & \\
\hline $25-34$ & 215 & 56.1 & $\checkmark$ & 0.940 \\
\hline $35-44$ & 104 & 27.2 & & \\
\hline $45-54$ & 27 & 7.0 & & \\
\hline $55-64$ & 14 & 3.7 & & \\
\hline $65+$ & 5 & 1.3 & & \\
\hline Total & 383 & 100 & & \\
\hline \multicolumn{5}{|l|}{ Education } \\
\hline Did not finish high school & 6 & 1.6 & & \\
\hline Finished high school & 46 & 12.0 & & \\
\hline Attended University & 40 & 10.4 & & \\
\hline Bachelors Degree & 223 & 58.2 & $\checkmark$ & 0.927 \\
\hline Postgraduate Degree & 68 & 17.8 & & \\
\hline Total & 383 & 100 & & \\
\hline \multicolumn{5}{|l|}{ Household Annual Income } \\
\hline USD 0 to 24,999 & 80 & 20.9 & & \\
\hline USD 25,000 to 49,999 & 117 & 30.5 & $\checkmark$ & 1.141 \\
\hline USD 50,000 to 74,999 & 119 & 31.1 & & \\
\hline USD 75,000 to 99,999 & 40 & 10.4 & & \\
\hline USD 100,000 or higher & 27 & 7.0 & & \\
\hline Total & 383 & 100 & & \\
\hline \multicolumn{5}{|l|}{ Gender } \\
\hline Male & 196 & 51.2 & $\checkmark$ & 0.501 \\
\hline Female & 187 & 48.8 & & \\
\hline Total & 383 & 100 & & \\
\hline \multicolumn{5}{|c|}{ US Geographical Distribution } \\
\hline North-East & 83 & 21.7 & & \\
\hline Mid-West & 133 & 34.8 & & \\
\hline South & 90 & 23.5 & & \\
\hline West & 77 & 20.1 & & \\
\hline Total & 383 & 100 & & \\
\hline
\end{tabular}

Both the Fornell-Larker criterion and Heterotrait-Monotrait (HTMT) ratios were utilized to test discriminant validity, with the requirements for discriminant validity being met for all of the variable constructs (see Table 3). The square root of each constructs' AVE was found to be higher than its correlation with other constructs. HTMT ratios are all less than 0.90, with the exception of the HTMT ratio between the importance placed on physical apple attributes and the importance placed on commercial apple attributes (1), which is a higher ratio than that which is recommended. However, this does not represent a problem because the two constructs both measure the apple attribute importance, with one construct being intrinsic and the other extrinsic to the product. Additionally, the largest VIF was 1.338 and the average VIF was 1.158, indicating that there were no problems with multicollinearity [58]. 
Table 2. Scale loadings, reliabilities, and convergent validity.

\begin{tabular}{|c|c|c|c|c|}
\hline Scales and Items & $\begin{array}{l}\text { Factor } \\
\text { Loadings }\end{array}$ & $\begin{array}{l}\text { Cronbach's } \\
\text { Alpha }\end{array}$ & $\begin{array}{l}\text { Composite } \\
\text { Reliability }\end{array}$ & $\begin{array}{l}\text { Average Variance } \\
\text { Extracted }\end{array}$ \\
\hline Discerning Apple Buyer & & 0.836 & 0.877 & 0.504 \\
\hline How similar are Pink Lady and Cosmic Crisp & 0.741 & & & \\
\hline How similar are Granny Smith and Royal Gala & 0.731 & & & \\
\hline How similar are Pink Lady and Cripps Pink & 0.706 & & & \\
\hline How similar are McIntosh and Braeburn & 0.749 & & & \\
\hline How similar are Zestar! and Sweet Tango & 0.718 & & & \\
\hline How similar are Fuji and Red Delicious & 0.639 & & & \\
\hline How similar are Red Delicious and Golden Delicious & 0.680 & & & \\
\hline Importance of Apple Commercial Attributes & & 0.701 & 0.817 & 0.527 \\
\hline Importance of-Price & 0.702 & & & \\
\hline Importance of-Labelled as sustainable & 0.719 & & & \\
\hline $\begin{array}{c}\text { Importance of-Labelled as traditional varieties such as Royal } \\
\text { Gala, Braeburn, Granny Smith }\end{array}$ & 0.735 & & & \\
\hline $\begin{array}{l}\text { Importance of-Labelled as club apples such as Pink lady or } \\
\text { Cosmic Crisp }\end{array}$ & 0.747 & & & \\
\hline Importance of Apple Physical Attributes & & 0.723 & 0.825 & 0.543 \\
\hline Importance of-Colour of the skin is true to variety & 0.773 & & & \\
\hline Importance of-Smell is appealing & 0.700 & & & \\
\hline Importance of-Texture is soft & 0.793 & & & \\
\hline Importance of-Skin is free of visual blemishes & 0.673 & & & \\
\hline My Attitudes towards US Apple Growers & & 0.836 & 0.880 & 0.552 \\
\hline $\begin{array}{l}\text { I think that US growers have a longstanding tradition and lots of } \\
\text { experience in growing sustainable apples. }\end{array}$ & 0.728 & & & \\
\hline $\begin{array}{l}\text { I think that US apple growers contribute to the care and } \\
\text { maintenance of the landscape }\end{array}$ & 0.678 & & & \\
\hline $\begin{array}{l}\text { I think that US apple growers make active contributions to } \\
\text { preserve biodiversity }\end{array}$ & 0.841 & & & \\
\hline I think that US apple growers treat land resources responsible & 0.707 & & & \\
\hline $\begin{array}{l}\text { I think that social pressure on apple growers should be increased } \\
\text { as they are main agents of climate change. }\end{array}$ & 0.665 & & & \\
\hline I think that US apple growers are environmental conscious & 0.821 & & & \\
\hline Subjective Apple Knowledge & & 0.860 & 0.905 & 0.704 \\
\hline I understand a lot about apples & 0.821 & & & \\
\hline I am confident in my knowledge of apples & 0.810 & & & \\
\hline Among my friends I am the apple expert & 0.882 & & & \\
\hline I know more about apples than others do & 0.841 & & & \\
\hline
\end{tabular}

The conceptual framework and its overall structure was tested, resulting in a Goodness of Fit of 0.43 and a Normed Fit Index of 0.676. A Standardised Root Mean Square Residual of 0.074 was also achieved, and this indicated that adequacy of the overall model fit. The explanatory and predictive power of the conceptual model was also tested, and this resulted in average $\mathrm{R}^{2} / \mathrm{Q}^{2}$ values of $0.349 / 0.293$, which indicates that the model has overall weak/moderate explanatory power and moderate predictive relevance. However, some parts of the model were found to be stronger than other parts. The $\mathrm{R}^{2} / \mathrm{Q}^{2}$ scores of $0.248 / 0.336$ for discerning apple buyers would be considered weak in their explanatory power and moderate in their predictive relevance, but the score of $0.440 / 0.216$ for importance placed on commercial apple attributes, and 0.388/0.247 for importance placed on physical apple attributes indicate weak/moderate levels of explanatory power and small predictive relevance. The score of $0.321 / 0.372$ for attitudes towards US growers would be considered to have moderate explanatory power and medium predictive relevance. The structure of the model was confirmed to be fit for hypothesis testing due to the adequate 
model fit, the weak to moderate explanatory power, and the weak to medium predictive accuracy. Table 4 and Figure 2 show the results of the hypothesis testing.

Table 3. Scale discriminant validity.

\begin{tabular}{|c|c|c|c|c|c|}
\hline Fornell-Larcker Criterion & $\begin{array}{l}\text { Discerning } \\
\text { Apple Buyer }\end{array}$ & $\begin{array}{c}\text { Importance of } \\
\text { Apple Commercial } \\
\text { Attributes }\end{array}$ & $\begin{array}{c}\text { Importance of } \\
\text { Apple Physical } \\
\text { Attributes }\end{array}$ & $\begin{array}{c}\text { Attitudes } \\
\text { towards US } \\
\text { Apple Growers }\end{array}$ & $\begin{array}{c}\text { Subjective } \\
\text { Apple } \\
\text { Knowledge }\end{array}$ \\
\hline Discerning Apple Buyer & 0.710 & & & & \\
\hline $\begin{array}{l}\text { Importance of Apple } \\
\text { Commercial Attributes }\end{array}$ & 0.638 & 0.726 & & & \\
\hline $\begin{array}{c}\text { Importance of Apple Physical } \\
\text { Attributes }\end{array}$ & 0.571 & 0.719 & 0.737 & & \\
\hline $\begin{array}{c}\text { Attitudes towards US Apple } \\
\text { Growers }\end{array}$ & 0.503 & 0.476 & 0.501 & 0.743 & \\
\hline Subjective Apple Knowledge & 0.484 & 0.426 & 0.360 & 0.548 & 0.839 \\
\hline \multicolumn{6}{|l|}{ Heterotrait-Monotrait Ratio } \\
\hline $\begin{array}{l}\text { Discerning Apple Buyer } \\
\text { Importance of Apple } \\
\text { Commercial Attributes }\end{array}$ & 0.831 & & & & \\
\hline $\begin{array}{c}\text { Importance of Apple Physical } \\
\text { Attributes }\end{array}$ & 0.713 & 1 & & & \\
\hline $\begin{array}{c}\text { Attitudes towards US Apple } \\
\text { Growers }\end{array}$ & 0.588 & 0.614 & 0.618 & & \\
\hline Subjective Apple Knowledge & 0.566 & 0.546 & 0.417 & 0.635 & \\
\hline
\end{tabular}

Table 4. Path coefficients and hypothesis testing results.

\begin{tabular}{|c|c|c|c|}
\hline Hypothesised Relationship & Coefficient & T Stat & $p$ Value \\
\hline H1a: Objective Apple Knowledge -> Discerning Apple Buyer & -0.008 & 0.191 & 0.848 \\
\hline H1b: Subjective Apple Knowledge -> Discerning Apple Buyer & 0.456 & 11.929 & 0.000 \\
\hline H2a: Gender -> Discerning Apple Buyer & -0.027 & 0.627 & 0.530 \\
\hline H2b: Age -> Discerning Apple Buyer & -0.077 & 1.773 & 0.076 \\
\hline H2c: Education -> Discerning Apple Buyer & 0.068 & 1.511 & 0.131 \\
\hline H2d: Income -> Discerning Apple Buyer & -0.054 & 1.206 & 0.228 \\
\hline H3a: Objective Apple Knowledge -> My Attitudes towards US Apple Growers & -0.086 & 2.133 & 0.033 \\
\hline H3b: Subjective Apple Knowledge -> My Attitudes towards US Apple Growers & 0.536 & 10.553 & 0.000 \\
\hline H4a: Gender -> My Attitudes towards US Apple Growers & -0.006 & 0.129 & 0.898 \\
\hline H4b: Age -> My Attitudes towards US Apple Growers & 0.031 & 0.729 & 0.466 \\
\hline H4c: Education -> My Attitudes towards US Apple Growers & 0.126 & 2.134 & 0.033 \\
\hline H4d: Income -> My Attitudes towards US Apple Growers & 0.005 & 0.140 & 0.889 \\
\hline H5: Discerning Apple Buyer -> Importance of Apple Physical Attributes & 0.428 & 7.142 & 0.000 \\
\hline H6: My Attitudes towards US Apple Growers -> Importance of Apple Physical Attributes & 0.286 & 4.776 & 0.000 \\
\hline H7: Discerning Apple Buyer -> Importance of Apple Commercial Attributes & 0.534 & 9.267 & 0.000 \\
\hline H8: My Attitudes towards US Apple Growers -> Importance of Apple Commercial Attributes & 0.208 & 3.586 & 0.000 \\
\hline
\end{tabular}




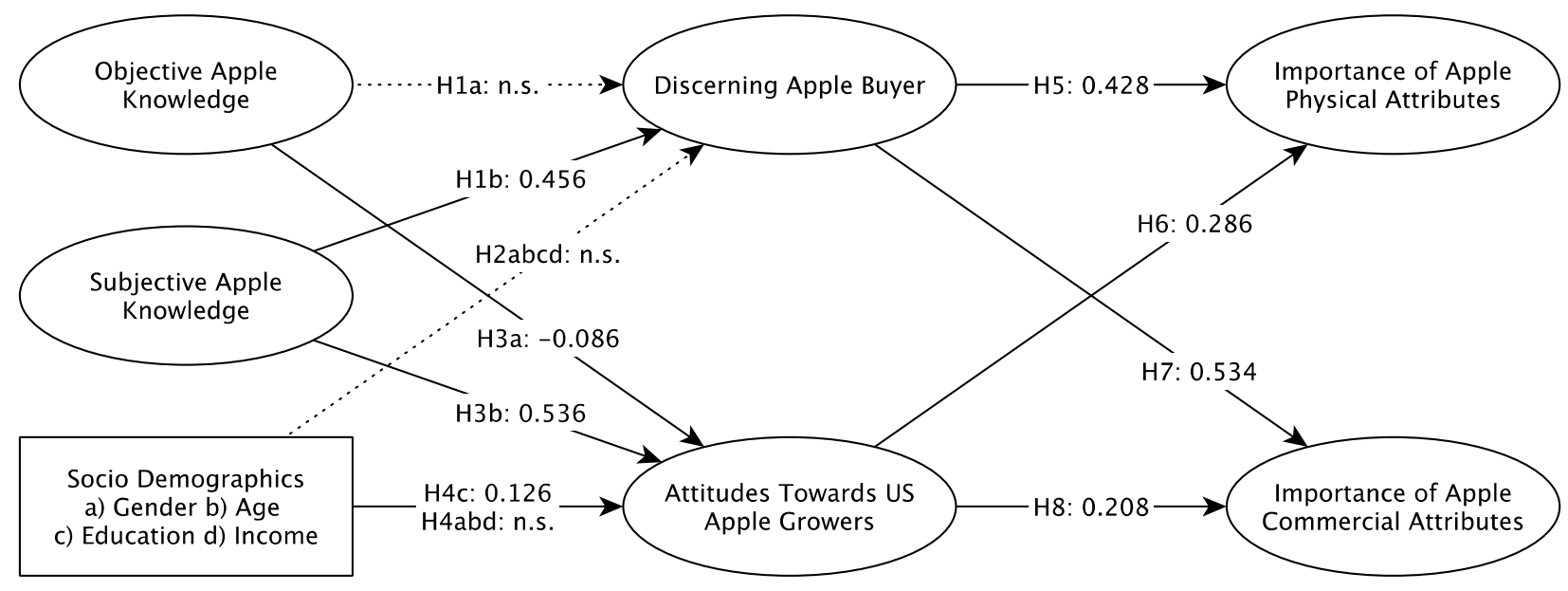

Figure 2. Results of the conceptual model.

\section{Discussion}

The present study explored key factors determining the importance that US apple consumers placed on physical and commercial apple attributes. Overall, the proposed model was found to have an adequate fit and good explanatory and predictive power. The results emphasised the importance of subjective knowledge as the most important factor determining the discernment of buyers and attitudes towards US growers. Objective knowledge and sociodemographic factors other than education were not found to have any impact. The discernment as a buyer and the ability to distinguish apple varieties had the greatest impact on the importance that US consumers placed on physical and commercial product attributes. Additionally, attitudes towards growers impacted the importance consumers placed on both types of attributes.

Subjective knowledge is a strong driver of buyer discernment and can be explained by the fact that consumers who feel that they have good or expert apple knowledge may see variations across apple characteristics. These findings echo recent studies of wine consumer knowledge presenting different types of consumers with varying levels of knowledge [38,44].

The results concerning buyer discernment as a predictor of the importance that US consumers place on physical and commercial attributes can be explained as follows; being able to distinguish varieties implies a certain degree of apple variety knowledge in terms of appearance, taste, texture, and smell. The distinction between more traditional varieties and club varieties is made through commercial features of the product [55]. This is commonly achieved through branding, and signalled to the consumer through slogans, pricing, labelling, and packaging.

In a similar manner, attitudes towards US growers determine both the importance placed on physical and commercial apple attributes. This supports the findings of Robertson et al. (2018) which showed that consumers with self-reported expertise focused on news sources and other information regarding apple production, and were likely to form stronger attitudes around production processes [66]. In a consumers' mind growers may represent and oversee products, the types of production and production processes, and their respective impacts on people and environment. The types of production and the production process used impact both the physical product and the commercial factors of the product alike. For this reason, consumer attitudes towards growers may be seen as strong driver.

\subsection{Practical Implications}

Results of this research are relevant to different actors within the horticultural industry and the US food retail industry. US fruit growers may wish to capitalise on the findings related to buyer discernment. Growers can contribute to consumer education and help 
to improve the varietal knowledge which consumers possess; this may, in turn, lead to brand loyalty. In local shops, at the farm gate, or in online stores information about taste, consumption and processing is very important. The identification of apple variants, and the highlighting of an apples' pedigree may be interesting for consumers. This could also help to improve the varietal knowledge that consumers have, and help them make more informed decisions when buying apples. Retailers may contribute in a similar manner, highlighting varietal information, the type of production and production processes used via quick response codes.

Given that consumer attitudes are a strong driver of their preferences, growers and grower associations should consider action outlining positive health and societal contributions which exist beyond food production. This impacts the public perception of the horticultural industry positively, and allows growers to both establish and keep their social licence to operate as fruit growers.

\subsection{Limitation and Suggestions for Future Research}

The data used in this study originate from the marketplace Amazon-Mechanical Turk (Mturk) [56]. Within this marketplace, wages of survey respondents are driven by market forces through the requesters posting their surveys and offering compensation. Ten years ago, Mturk was criticised for its low pricing, labour issues, and data quality; however, in 2021, the crowdsourcing platform is now widely used in the social sciences for data collection. Mturk samples and have been found to be equal to other forms of convenience samples [56-58]. A sample of Mturk workers is unlikely to be of the same quality than a representative national sample, but comparable to college samples and other forms of convenience samples [56].

Future research could focus on consumer preferences for apple trees and canopy shapes, as self-sufficiency and do-it-yourself are currently popular horticultural trends within gardening as a result of the COVID-19 pandemic, and which are predicted to remain popular $[67,68]$.

In addition, studies may choose to address apple attribute preferences, such as those explored by Bir et al. (2021) [69] who studied attributes of horticultural products using a best-worst approach, evaluating the trade off consumers make among products consisting of various attribute bundles. This study focused on a pictorial experimental design [69]. A similar approach may also be suitable when studying apples and consumers who are novices, or when conducting research with children. Combining the best-worst methodology and latent class analysis on apple attributes would be appropriate in such a study context. The combination enables us to explore the trade offs consumers make when choosing products, and building consumer classes according to common preferences. Within this context the research may consider varieties that are utilized for processing, such as varieties used in juicing and baking, as well as eating fresh. Additionally, a cross-country comparison investigating extrinsic and intrinsic attributes may be promising.

Further research could be framed within the context of buying local and focus on consumers' willingness to pay for apples produced in specific states or regions in different online scenarios. Such a study could be positioned within the context of connected consumerism, a trend gaining increasing importance due to the COVID-19 pandemic [67]. Connected consumers buy and communicate online with local businesses, are interested in production practices, and are also concerned about the impact of the coronavirus pandemic on both communities and businesses [67]. Examination of the level of connectedness between consumers and apple growers is an area which currently remains unexplored.

\section{Conclusions}

This study focused on attribute preferences of US fruit consumers, and, more specifically, the factors that determine these preferences. Results show that subjective knowledge was the most important factor determining the discernment of buyers and attitudes towards US growers. Objective knowledge was not found to have any impact, while only 
education as a sociodemographic factor had impact. The discernment as a buyer and the ability to distinguish apple varieties had the greatest impact on the importance that US consumers placed on apple attributes. Additionally, attitudes towards growers impacted the importance consumers placed on intrinsic and extrinsic apple attributes.

Author Contributions: Conceptualization, R.M. and D.L.D.; methodology, D.L.D.; software, D.L.D.; validation, T.B., R.M. and D.L.D.; formal analysis, D.L.D.; investigation, R.M.; resources, R.M.; data curation, D.L.D. writing—original draft preparation, R.M.; writing—review and editing, R.M., D.L.D., T.B. All authors have read and agreed to the published version of the manuscript.

Funding: No specific funding has been attributed to the project.

Institutional Review Board Statement: The study was conducted in accordance with the Declaration of Helsinki, and the protocol was approved by the Human Ethics Committee at Lincoln University, New Zealand in 2021 (HEC2021-20).

Informed Consent Statement: All participants gave their informed consent for inclusion before they participated in the study.

Data Availability Statement: The data presented in this study are available on request from the corresponding author.

Conflicts of Interest: The authors declare no conflict of interest in the context of this publication. The funders had no role in the design of the study; in the collection, analyses, or interpretation of data; in the writing of the manuscript or in the decision to publish the results.

\section{References}

1. Ceschi, S.; Canavari, M.; Castellini, A. Consumer's preference and willingness to pay for apple attributes: A choice experiment in large retail outlets in Bologna (Italy). J. Int. Food Agribus. Mark. 2018, 30, 305-322. [CrossRef]

2. Meyerding, S.G.; Merz, N. Consumer preferences for organic labels in Germany using the example of apples-Combining choice-based conjoint analysis and eye-tracking measurements. J. Clean. Prod. 2018, 181, 772-783. [CrossRef]

3. Boca, G.D. Factors influencing consumer behavior in sustainable fruit and vegetable consumption in maramures county, Romania. Sustainability 2021, 13, 1812. [CrossRef]

4. Zaikin, A.A.; McCluskey, J.J. Consumer preferences for new technology: Apples enriched with antioxidant coatings in Uzbekistan. Agric. Econ. 2013, 44, 513-521. [CrossRef]

5. Blanke, M.; Burdick, B. Food (miles) for thought-energy balance for locally grown versus imported apple fruit. Environ. Sci. Pollut. Res. 2005, 12, 125-127. [CrossRef] [PubMed]

6. Legun, K.; Burch, K. Robot-ready: How apple producers are assembling in anticipation of new AI robotics. J. Rural. Stud. 2021, 82, 380-390. [CrossRef]

7. Funke, K.; Blanke, M. Spatial and Temporal Enhancement of Colour Development in Apples Subjected to Reflective Material in the Southern Hemisphere. Horticulturae 2021, 7, 2. [CrossRef]

8. Fresh Facts. Apples. 2019. Available online: https://www.freshfacts.co.nz/ (accessed on 3 November 2021).

9. USDA. On the Map: California, Florida, and Washington Are Nation's Largest Fruit-Producing States. 2021. Available online: https:/ / www.ers.usda.gov/amber-waves/2011/june/on-the-map/ (accessed on 12 November 2021).

10. Karkee, M.; Zhang, Q.; Silwal, A. Agricultural Robots for Precision Agricultural Tasks in Tree Fruit Orchards. In Innovation in Agricultural Robotics for Precision Agriculture. Progress in Precision Agriculture; Bechar, A., Ed.; Springer: Cham, Switzerland, 2021. [CrossRef]

11. Tibbets, J.H. Not too far from the tree. Mech. Eng. 2018, 140, 28-33. [CrossRef]

12. Yue, C.; Tong, C. Consumer preferences and willingness to pay for existing and new apple varieties: Evidence from apple tasting choice experiments. HortTechnology 2011, 21, 376-383. [CrossRef]

13. US Apple. Apple Varieties. 2021. Available online: https://usapple.org/apple-varieties (accessed on 26 November 2021).

14. Canavari, M.; Castellini, A.; Spadoni, R. Challenges in Marketing Quality Food Products. J. Int. Food Agribus. Mark. 2010, 22, 203-209. [CrossRef]

15. Harker, F.R.; Gunson, F.A.; Jaeger, S.R. The case for fruit quality: An interpretive review of consumer attitudes, and preferences for apples. Postharvest Biol. Technol. 2003, 28, 333-347. [CrossRef]

16. De Hooge, I.E.; Oostindjer, M.; Aschemann-Witzel, J.; Normann, A.; Loose, S.M.; Almli, V.L. This apple is too ugly for me!: Consumer preferences for suboptimal food products in the supermarket and at home. Food Qual. Prefer. 2017, 56, 80-92. [CrossRef]

17. Bolos, L.A.; Lagerkvist, C.J.; Normann, A.; Wendin, K. In the eye of the beholder: Expected and actual liking for apples with visual imperfections. Food Qual. Prefer. 2021, 87, 1-9. [CrossRef]

18. Kelley, K.; Hyde, J.; Travis, J.; Crassweller, R. Assessing consumer preferences of scab-resistant apples: A sensory evaluation. HortTechnology 2010, 20, 885-891. [CrossRef] 
19. Onik, J.C.; Wai, S.C.; Li, A.; Lin, Q.; Sun, Q.; Wang, Z.; Duan, Y. Melatonin treatment reduces ethylene production and maintains fruit quality in apple during postharvest storage. Food Chem. 2021, 337, 1-8. [CrossRef]

20. Cofelice, M.; Lopez, F.; Cuomo, F. Quality control of fresh-cut apples after coating application. Foods 2019, 8, 189. [CrossRef]

21. Šernaitè, L.; Rasiukevičiūtè, N.; Valiuškaitè, A. Application of plant extracts to control postharvest gray mold and susceptibility of apple fruits to B. cinerea from different plant hosts. Foods 2020, 9, 1430. [CrossRef]

22. Endrizzi, I.; Aprea, E.; Betta, E.; Charles, M.; Zambanini, J.; Gasperi, F. Investigating the Effect of Artificial Flavours and External Information on Consumer Liking of Apples. Molecules 2019, 24, 4306. [CrossRef]

23. Poles, L.; Gentile, A.; Giuffrida, A.; Valentini, L.; Endrizzi, I.; Aprea, E.; Gasperi, F.; Distefano, G.; Artioli, G.; La Malfa, S.; et al Role of fruit flesh cell morphology and MdPG1 allelotype in influencing juiciness and texture properties in apple. Postharvest Biol. Technol. 2020, 1-10. [CrossRef]

24. Loureiro, M.L.; McCluskey, J.J.; Mittelhammer, R.C. Assessing consumer preferences for organic, eco-labeled, and regular apples J. Agric. Resour. Econ. 2001, 404-416. Available online: https:/ /www.jstor.org/stable/ 40987117 (accessed on 15 November 2021).

25. Fernández-Serrano, P.; Tarancón, P.; Besada, C. Consumer Information Needs and Sensory Label Design for Fresh Fruit Packaging. An Exploratory Study in Spain. Foods 2021, 10, 72. [CrossRef]

26. Denver, S.; Jensen, J.D. Consumer preferences for organically and locally produced apples. Food Qual. Prefer. 2014, 31, 129-134. [CrossRef]

27. Sackett, H.M.; Shupp, R.S.; Tonsor, G.T. Discrete Choice Modeling of Consumer Preferences for Sustainably Produced Steak and Apples. In Presented at the Agricultural and Applied Economics Association (AAEA) Conferences, 2012 AAEA/EAAE Food Environment Symposium, 30-31 May 2012; Tufts University: Boston, MA, USA, 2012.

28. Moser, R.; Raffaelli, R. Consumer preferences for sustainable production methods in apple purchasing behaviour: A nonhypothetical choice experiment. Int. J. Consum. Stud. 2012, 36, 141-148. [CrossRef]

29. Olynk, N.J.; Tonsor, G.T.; Wolf, C.A. Consumer willingness to pay for livestock credence attribute claim verification. J. Agric. Resour. Econ. 2010, 261-280. [CrossRef]

30. Sackett, H.M.; Shupp, R.; Tonsor, G. Consumer perceptions of sustainable farming practices: A Best-Worst scenario. Agric. Resour. Econ. Rev. 2013, 42, 275-290. [CrossRef]

31. Marette, S.; Disdier, A.C.; Beghin, J.C. A comparison of EU and US consumers' willingness to pay for gene-edited food: Evidence from apples. Appetite 2021, 159, 1-11. [CrossRef]

32. Wong, R.; Kim, S.; Chung, S.J.; Cho, M.S. Texture preferences of Chinese, Korean and US consumers: A case study with apple and pear dried fruits. Foods 2020, 9, 377. [CrossRef]

33. Wilson, L.; Lusk, J.L. Consumer willingness to pay for redundant food labels. Food Policy 2020, 97, 1-14. [CrossRef]

34. Wang, Q.; Sun, J.; Parsons, R. Consumer preferences and willingness to pay for locally grown organic apples: Evidence from a conjoint study. HortScience 2010, 45, 376-381. [CrossRef]

35. Endrizzi, I.; Torri, L.; Corollaro, M.L.; Demattè, M.L.; Aprea, E.; Charles, M.; Gasperi, F. A conjoint study on apple acceptability: Sensory characteristics and nutritional information. Food Qual. Prefer. 2015, 40, 39-48. [CrossRef]

36. Oh, C.O.; Herrnstadt, Z.; Howard, P.H. Consumer willingness to pay for bird management practices in fruit crops. Agroecol. Sustain. Food Syst. 2015, 39, 782-797. [CrossRef]

37. Kim, S.W.; Brorsen, B.W.; Lusk, J. Not everybody prefers organic food: Unobserved heterogeneity in US consumers' preference for organic apple and milk. Appl. Econ. Lett. 2018, 25, 9-14. [CrossRef]

38. Holdershaw, J.; Konopka, R. Consumer knowledge of country of origin of fresh food at point of purchase. J. Promot. Manag. 2018, 24, 349-362. [CrossRef]

39. Taylor, M.; Granatstein, D. A cost comparison of organic and conventional apple production in the state of Washington. Crop Manag. 2013, 12, 1-7. [CrossRef]

40. Drkenda, P.; Ćulah, A.; Spaho, N.; Akagić, A.; Hudina, M. How Do Consumers Perceive Sensory Attributes of Apple? Foods 2021, 10, 2667. [CrossRef]

41. Kleine-Kalmer, R.; Profeta, A.; Daum, D.; Enneking, U. Pre-Launch Exploration of Consumer Willingness to Purchase Seleniumand Iodine-Biofortified Apples-A Discrete Choice Analysis of Possible Market Settings. Nutrients 2021, 13, 1625. [CrossRef]

42. Hurgobin, Y.; Le Floch, V.; Lemercier, C. Effect of multiple extrinsic cues on consumers' willingness to buy apples: A scenariobased study. Food Qual. Prefer. 2020, 81, 1-9. [CrossRef]

43. Ellis, D.; Mattison Thompson, F. The effect of wine knowledge type on variety seeking behavior in wine purchasing. J. Wine Res. 2018, 29, 71-86. [CrossRef]

44. Ellis, D.; Caruana, A. Consumer wine knowledge: Components and segments. Int. J. Wine Bus. Res. 2018, 30, 277-291. [CrossRef]

45. Peschel, A.O.; Grebitus, C.; Steiner, B.; Veeman, M. How does consumer knowledge affect environmentally sustainable choices? Evidence from a cross-country latent class analysis of food labels. Appetite 2016, 106, 78-91. [CrossRef]

46. Hwang, H.; Nam, S.J. The influence of consumers' knowledge on their responses to genetically modified foods. GM Crops Food 2021, 12, 146-157. [CrossRef] [PubMed]

47. Tait, P.R.; Saunders, C.M.; Dalziel, P.C.; Rutherford, P.; Driver, T.; Guenther, M. California Apple Consumer Consumption Behaviours and Product Preferences: A Latent Class Analysis; AERU Research Report No. 366, prepared for Unlocking Export Prosperity Research Programme; Agribusiness and Economics Research Unit, Lincoln University: Lincoln, New Zealand, 2021. 
48. Maples, M.; Morgan, K.L.; Interis, M.G.; Harri, A. Who Buys Food Directly from Producers in the Southeastern United States? J. Agric. Appl. Econ. 2015, 45, 509-518. [CrossRef]

49. Fastring, D.; Nadorff, D.; DeShong, H. The Influence of Rurality on Fruit and Vegetable Intake and BMI: Findings in Mississippi Are Not Consistent with Those at the National Level. Int. J. Environ. Res. Public Health 2021, 18, 5021. [CrossRef]

50. Yue, C.; Gallardo, R.K.; Luby, J.; Rihn, A.; McFerson, J.R.; McCracken, V.; Iezzoni, A.F. An investigation of US apple producers' trait prioritization-evidence from audience surveys. HortScience 2013, 48, 1378-1384. [CrossRef]

51. Gallardo, R.K.; Hanrahan, I.; Yue, C.; McCracken, V.A.; Luby, J.; McFerson, J.R.; Carrillo-Rodriguez, L. Combining sensory evaluations and experimental auctions to assess consumerspreferences for fresh fruit quality characteristics. Agribusiness 2018, 34, 407-425. [CrossRef]

52. Uribe, R.; Infante, R.; Kusch, C.; Contador, L.; Pacheco, I.; Mesa, K. Do Consumers Evaluate New and Existing Fruit Varieties in the Same Way? Modeling the Role of Search and Experience Intrinsic Attributes. J. Food Prod. Mark. 2020, 26, 521-534. [CrossRef]

53. Jaeger, S.R.; Harker, F.R. Consumer evaluation of novel kiwifruit: Willingness-to-pay. J. Sci. Food Agric. 2005, 85, 2519-2526. [CrossRef]

54. Cheng, H.T.; Criner, G.K.; Kezis, A.S. The impact of consumer characteristics on preferences for selected apple varieties. J. Food Prod. Mark. 1997, 3, 1-11. [CrossRef]

55. Asioli, D.; Canavari, M.; Malaguti, L.; Mignani, C. Fruit branding: Exploring factors affecting adoption of the new pear cultivar 'Angelys' in Italian large retail. Int. J. Fruit Sci. 2016, 16, 284-300. [CrossRef]

56. Litman, L.; Robinson, J. Conducting Online Research on Amazon Mechanical Turk and Beyond; Sage Publications: Thousand Oaks, CA, USA, 2020

57. Aguinis, H.; Villamor, I.; Ramani, R.S. MTurk research: Review and recommendations. J. Manag. 2021, 47, 823-837. [CrossRef]

58. Goodman, J.K.; Cryder, C.E.; Cheema, A. Data collection in a flat world: The strengths and weaknesses of Mechanical Turk samples. J. Behav. Decis. Mak. 2013, 26, 213-224. [CrossRef]

59. Hair, J.F.; Howard, M.C.; Nitzl, C. Assessing measurement model quality in PLS-SEM using confirmatory composite analysis. J. Bus. Res. 2020, 109, 101-110. [CrossRef]

60. Hair, J.F.; Risher, J.J.; Sarstedt, M.; Ringle, C.M. When to use and how to report the results of PLS-SEM. Eur. Bus. Rev. 2019, 31, 2-14. [CrossRef]

61. Hair, J.F.; Hult, G.T.M.; Ringle, C.M.; Sarstedt, M. A Primer on Partial Least Squares Structural Equation Modeling (PLS-SEM); Sage: Thousand Oaks, CA, USA, 2017.

62. Chin, W.; Cheah, J.-H.; Liu, Y.; Ting, H.; Lim, X.-J.; Cham, T.H. Demystifying the role of causal-predictive modeling using partial least squares structural equation modeling in information systems research. Ind. Manag. Data Syst. 2020, 120, 2161-2209. [CrossRef]

63. Hair, J.F.; Ringle, C.M.; Sarstedt, M. PLS-SEM: Indeed a silver bullet. J. Mark. Theory Pract. 2011, 19, 139-152. [CrossRef]

64. Fornell, C.; Larcker, D.F. Evaluating Structural Equation Models with Unobservable Variables and Measurement Error. J. Mark. Res. 1981, 18, 39-50. [CrossRef]

65. Henseler, J.; Ringle, C.M.; Sarstedt, M. A new criterion for assessing discriminant validity in variance-based structural equation modeling. J. Acad. Mark. Sci. 2015, 43, 115-135. [CrossRef]

66. Robertson, J.; Ferreira, C.; Botha, E. The influence of product knowledge on the relative importance of extrinsic product attributes of wine. J. Wine Res. 2018, 29, 159-176. [CrossRef]

67. Hoekstra, J.C.; Leeflang, P.S. Marketing in the era of COVID-19. Ital. J. Mark. 2020, 4, 249-260. [CrossRef]

68. Pulighe, G.; Lupia, F. Food first: COVID-19 outbreak and cities lockdown a booster for a wider vision on urban agriculture. Sustainability 2020, 12, 5012. [CrossRef]

69. Bir, C.; Lai, J.; Thompson, N.M.; Widmar, N.O. Evaluating the Inclusion of Words and/or Pictures in Best-Worst Scaling Experiments. J. Int. Food Agribus. Mark. 2021, 1-25. [CrossRef] 